\title{
The Powers of the Exploited and the Social Ontology of Praxis
}

\author{
Michael Hardt and Toni Negri
}

\begin{abstract}
This contribution is the first part of a debate between Michael Hardt/Toni Negri and David Harvey on the occasion of Marx's bicentenary. The discussion focuses on the question of what capitalism looks like today and how it can best be challenged. This contribution asks: In what type of capitalist society are we living today? And what is the Marxian praxis that we need to challenge it? First, this paper analyses capitalism in respect to the extraction of value from the common, immaterial labour, digitisation, automation, and finance capital. The greatest abstraction in the productive process of value, in its implementation of languages, codes, immaterial articulations of being together, cooperation, affective elements, and so forth presents also in the multitude the virtuality of an extraordinary potential of resistance and autonomy from capital. Second, the paper discusses what forms of praxis are needed today. Marxian ontology is constituted and always renewed by class struggle, by the material antagonism that distributes the elements of real being and by the continuous excess of value that living labour expresses. Today, we discuss Marxian praxis in a society where intelligence is put to work at the centre of the productive process. Here emerges with great force the theme of the liberation of humans from work, on the basis of the transformations of work. Marx demonstrates how much cognitive and intellectual activity is central to production, and how much fixed capital is mixed with cognitive labour. In this context, the notion of the appropriation of fixed capital is of key importance for class struggles.
\end{abstract}

Keywords: Marx, bicentenary, 200th anniversary, capitalism, exploitation, praxis

\section{Introduction}

David Harvey (2017) reminds us that Marx's preferred definition of capital is "value in motion" - productive, circulatory, and reproductive movement; temporal and spatial movement; movement from one phase to another; continuous and discontinuous movement. What interests us primarily here is the discontinuous movement of capital, its historical transformation, and thus its periodization. We are convinced that for several years has been emerging a new configuration of the "technical composition" of living labour and the "organic composition" of capital. This new configuration marks a transformation of productive forces and the relations that are situated in production, in the mode of production. We have left the era in which capital organised exploitation primarily via the norms and discipline of large-scale industry and we are entering a phase in which capital tends to develop in large part through forms of the extraction of value from "common goods" and from the ever vaster social organization of the common in the form of the expanded cooperation of living labour.

This development was born of class struggle, as Marx would say, and thus of workers struggles and social movements that made impossible the reproduction of the industrial mode of accumulation and thus put in peril the maintenance of the capitalist order. We situate this rupture and the beginnings of the new dialectical structuring of class struggle, along with the progressive formation of a new mode of postindustrial production, around the end of the 1960s and the beginning of the 1970s. With this in mind, we can begin to describe, the contemporary figures of "value in motion," that is, the organic composition of capital and the technical composition of living 
labour that today characterise the processes of capitalist development and valorisation.

On the basis of these premises - the periodization of capitalist society driven by resistances to it - we can respond to the two questions that have been posed for us in this essay: In what type of capitalist society are we living today? And what is the Marxian praxis that we need to challenge it?

\section{Capitalism Today}

With regard to the first question we want to focus primarily on the new modes of exploitation as well as the power and relative autonomy of social production in the face of them. Before addressing this directly, however, we should articulate a bit more fully our understanding of the periodization of capitalist production and control. In fact, once we pose class struggle as the motor defining the transformation of the structures of capitalism from the second half of the 20th century to today, we can see more clearly the new figures that labour, exploitation, and, consequently, the very nature of capital.

Our first observation regarding the contemporary figure of capital is aimed at revealing the mutation of living labour and thus clarifying how its productivity has been intensified through the growing networks of cooperation in the mode of production. Insofar as labour-power is shown in Marx's $(1867 ; 1885 ; 1894)$ Capital as "living labour" that increases its own productivity in simple and extended cooperation, and further in the organisation of manufacturing and large-scale industry; and insofar as the capitalist organisation of labour progressively re-enforces cooperation and intensifies it to the point of constructing it as a social activity; then when we enter in the current phase of capitalist development characterised by cognitive and social production, the social cooperation of labour is enormously enhanced, immersed as it is in a set of communicative networks and digital connections that increasingly permeate all the industrial assets, services, agricultural systems, and all the other figures of the economic organisation of society. Capital is, in fact, increasingly valorised by cooperative social flows in which muscles, languages, affects, codes, and images are subsumed within the material processes of production.

The neoliberal "counter-revolution" presents us with this scene following the thirtyyear cycle of class struggle after World War 2 and the subsequent workers' defeat at the end of the 1970s. In the course of the last half century, the sectors of capitalist production and of society have been radically transformed, extending the primary sites of production from the factory to the social terrain. This is the meaning that should be given to the Marxian figures of the "real subsumption" of labour under capital - which can be extended to the subsumption of society itself under capital. This is not a matter only of the totalitarian extension of consumption and its eventual alienating effects (as followers of the Frankfurt School maintained), but also the incarnation of capitalist production in society, that is, in the languages of the market as in the vital connections of society. In order to re-establish profits, which could no longer be sufficiently sustained in the factories and traditional industries, capital strategically put to work the social terrain, and in society the mode of production came to be ever more closely interwoven with "forms of life."

How did we arrive at this situation? One narrative goes like this. A first passage was constituted by the simplification of industrial production introduced by automation. From the political point of view, this destroyed the resistance of the working class to exploitation and expelled the workers from the factory in the dominant parts of the world, thus forcing them to "put to work" - in order to resist and to survive - the 
society that surrounds them. In this way the productive power of labour came to be widely extended. Now, while the automated industrial processes continued increasingly to produce material goods, outside of the roboticised factories grew ever more complex integrated productive services that connected in social labour complex technologies and fundamental sciences, industrial services and welfare. Through the development of this tendency, digitalisation and computerisation became decisive (in a second phase) in the social structuring of capital - more important, so to speak, than automation. Digitalisation and computerisation articulated in society a transformation of the composition of labour-power, adequate to the new forms of technological command, renouncing definitively the worker composition that had been constructed in and by the industrial factory. This development is strongly tendential, which means that it is becoming hegemonic at a global level - unevenly, of course, but at certain times and in certain places with extraordinary accelerations.

Now we are in position to confront the concept of exploitation and, specifically, how exploitation is transformed when, through modifications of the mode of production, it becomes an extractive function at a social level. We have described how the capitalist initiative responded to the accumulation of resistances and revolts of the 1960 s and 70 s, destroying the factory and socialising the mode of production. Now we can recognise the further passage to the phase of social production, which some call the society of General Intellect. The passage from Fordism to post-Fordism inaugurates a new figure of the relationship between capital and labour, showing the progressive role of social production. In the Fordist period capitalist production was structured by disciplinary regimes and accumulation was realised and centralised by the profit generated in the expropriation of surplus value, in the space that linked industrial production and planned cooperation (in the Keynesian programmes) of social labour. In the post-Fordist period, in contrast, when productive knowledges and the capacity of cooperation are spread ever more widely throughout society and the new productivity of cognitive and affective forms of labour-power start to become hegemonic, capital extracts - for its own valorisation - the social wealth produced in common and, in this sense, tends to subsume the entire social field. At this point, in effect, the centrality of extraction inaugurates a new figure of exploitation.

This new figure of exploitation requires that we revise some of Marx's assumptions and methods. In the contemporary extractive processes, the quantities of surplus labour and surplus-value, which Marx defined in Capital according to an analytic of temporal measure, are redefined by the cooperative, cognitive, and social nature of valorisation. Consequently, the Marxian concept of exploitation - concentrated on the different "times" of the working day of the individual worker - seems to have exhausted its theoretical and political value. When Marx explains pedagogically that in the regime of waged labour workers receive the value produced during the first hours of the working day and that the capitalist expropriates the value produced during the remaining hours, he establishes an intimate relationship between exploitation and the organisation of production. This point is essential and remains equally foundational for understanding contemporary capitalist production. But that intimate relationship no longer has the same form as it did in the period that Marx studied. Today, instead, the connection between exploitation and its organisation are defined by an ever increasing distance. This is the point on which we can recognise, as we will develop below, how finance regards productive subjects from above, abstractly, and extracts value at a distance. The "real subsumption" here becomes predominant over the "formal subsumption" when society tends toward being completely enveloped by the machine of capitalist valorisation. 
This extraction of value, this planting of the valorisation on a cooperative, cognitive, and social figure of living labour, this taking possession of the common by capital, dispossessing the producers, may resemble the processes that Marx called "primitive accumulation" and that David Harvey (2003) has so effectively analysed in terms of "accumulation by dispossession" - but only in part. The "real subsumption" represents, in fact, a developed form of the organisation of the exploitation and the social division of labour. The extraction of value is thus never here a pure "dispossession" of pre-existing wealth but the appropriation of wealth produced and socially accumulated by labour-power. This new primitive accumulation of the socially produced commons by capital is not conducted by brute force but rather developed through a "rationality" by which we mean an adequation of the means to the ends of capitalist enrichment.

Let's return to the distance between the command over exploitation and the organisation of labour. It is clear that in this distance is present and is organised, in the hegemony of the extractive form of valorisation, a wide variety of figures of exploitation. That distance is not indifferent. It is rather a space of class struggle and the productive subjectivities that operate there, being more able to cooperate socially and to productively organise cooperation, are presented on the scene in a relatively autonomous way. Given that distance, the capitalist entrepreneurs fail to organise labour in a disciplinary way, and they also fail to forge new combinations or generate new productive forms of cooperation, as Joseph Schumpeter (2017/1934) theorised in the phase of large-scale industry. Capitalist entrepreneurial command is now projected in the sphere of finance. That is where capitalist entrepreneurs act, absorbed in financial activity and attentive to the fluctuations of stock markets. In contrast, there is determined here - in the long prospective of workers' history - a space of autonomy for living labour, which is paradoxical but decisive. Since workers have acquired a certain autonomy, they can put in action the productivity of their labour, which is very high, and thus have the capacity to pose a rupture with the capitalist productive system, articulating alternative proposals and the capacities to realise them. This is why today, in neoliberal society, the fairy tales produced by the social sciences in the service of the individualist ideologies of merit and success are aimed with full force at the class of workers, to make the distance of entrepreneurial command an irrelevant element and make the autonomy of living labour a mechanism functional to control.

It is important to note that our analysis of the relative autonomy of living labour in today's era dominated by social production does not imply that the forms of exploitation characterised by fatigue and pain have been done away with. It does not negate the alienation that is produced by physical labour and equally (sometimes in harsher forms) by immaterial labour. It does not, therefore, imagine that labour has somehow been rescued from the inferno of exploitation. On the contrary, today's social forms of labour, precisely in the relative autonomy in which they are posed within the social organisation of labour, are ever more subject to duress and injury, which result not only from being physically exploitation but also being so emotionally and psychically.

This leads us to one further observation, which regards the transformation of capital today into a financial-extractive force. When finance emerged as a significant component of the capitalist mode of production in the late 19th and early 20th centuries, it constituted a powerful supplement to industrial capital. Finance offered instruments of abstraction and centralisation that facilitated the passage from the stage of enlarged cooperation and manufacturing to the industrial structures commanded by the great corporations and their monopolies, as well as serving as a potent weapon in the arsenal of imperialist projects. In the course of the 20th century, however, this 
relationship was progressively inverted to the point that today finance dominates industry, imposing on it the fundamental norms of production (that is, of valorisation and exploitation). Behind financial rule and its ever more complex instruments, capital can seem to accumulate value that is free for the taking, a natural gift, terra nullius.

In reality, finance capital accumulates through the capture and extraction of the value of the common, including values and materials hidden in the earth as well as products of social cooperation. It is clear that, even though the passage to the command of finance capital can be explained by the formation of global markets and the decline of national industrial economies, by the repeated crises and the deepening of speculative operations, the hegemony of finance must still be understood in terms of the mode of production: finance functions as an apparatus of capture of natural and social values, as a power of the extraction of the common. Its processes of extraction, in fact, follow the traces of the common.

In contrast to profits generated in industry, financial forms of extraction are developed on the forms of wealth that in large part pre-exist the investment of capital. Whereas the automobile is product of the factory, oil and coal exist in the earth, although, of course, the extraction is itself organised in processes of production, refinement, and distribution. The distinction is even clearer when one looks at social intelligence, social relations, and territories of sociality. Whereas in the factory workers cooperate on the basis of schemes and disciplines dictated by the capitalist, here - in social production - value is produced through social cooperation not directly organized by capital. Social cooperation is in this sense relatively autonomous. All of that emphasises, once again, how the relationship of capital has been ruptured: in the face of that relative autonomy of cooperation, finance takes the form of an extractive industry.

The totalisation of the world of labour, the absorbing of production within reproduction, the financial sublimation of value in the frame of the "real subsumption" of productive society in capital have often been recognised in the theoretical developments of "Western Marxism." But on the basis of what we have said so far, it is necessary to go beyond that. Defining this "beyond" means advancing on three terrains that we have begun to explore and reveal the "subjective" implications.

First is the terrain of labour, where the cooperative association of labour-power redefines the concept of the working class, showing it to be a multitudinous set of labouring singularities, a multiplicity of material and immaterial powers. In cooperative association, these singular powers configure virtually a plural recomposition of the working class, a recomposition through flows of subjectivation. We call that figure of the working class "multitude."

Second, with respect to the concept of exploitation, engaging the new figures of alienation and the reification of labour means delving into the effects of subjectivation revealed by the new relationships between variable capital and fixed capital. This leads us to ask if it is possible that, wherever exploitation effects the cognitive, social, and cooperative components of living labour the dialectic of capture and appropriation of value-labour by capital is broken. And it leads us to ask too if alienated labour, appearing as a "second nature" of labour-power, is in position to break the order of exploitation (and, if so, to what extent and with what force). But we will return to this later.

Third, one must analyse how to this new nature of capital and its extractive mechanisms correspond ontologically the social dynamic of the common. Once the relations of discipline and control of massified industrial labour have declined and the 
old criteria of measure of the value of labour (adequate to that old stage of development) have failed, extractive expropriation must be explained, as we said, in correspondence to the figure of the common. How can this be done? A first response can be that when social labour, in its different forms and levels, becomes increasingly powerful in productive activities (employing social and scientific knowledges, languages and code, schemes of cooperation and affective relations), one can observe that the same characteristics of social production, which offer the key to the extraction and accumulation of wealth on the part of finance, give also the figure of the multitude. If finance extracts value from the common, that is because it extracts it from the multitude. Both sides of this relation, or really the tension between exploitation and living labour, are thus contained in the progressively abstract nature of social production.

All readers of Marx know how he employs the concept of abstract labour as the key to understanding the value of capitalist exchange. Today, in many respects, the quantities of abstract labour and the value represented in it increase exponentially when production becomes social and when the working class appears in the figure of the multitude. When workers interiorise knowledges, for example, and socially develop them in cooperation, then the value that the multitude produces is ever larger and, in line with Marx's thinking, ever more abstract. But the greatest abstraction in the productive process of value, in its implementation of languages, codes, immaterial articulations of being together, cooperation, affective elements, and so forth presents also in the multitude the virtuality of an extraordinary potential of resistance and autonomy from capital.

This abstraction of labour and the valorising dimension that corresponds to it are related to the socially produced common and to its multitudinous subjectivation. The common tends to be both the foundation and the result of contemporary production. And like capital, the common too is here doubly defined by the class struggle of the multitude, both as foundation of the capitalist extraction of value and as potential for autonomy and resistance.

\section{Praxis}

This brings us to the second question we posed at the outset: What forms of Marxian praxis are necessary in this context? It should be obvious from what we have said thus far that Marxian theory appears as an ontology of the power of labour, without any interruption from his early manuscripts to his final articles on Wagner. We give particular importance to the Grundrisse (Marx 1857/588) in this regard because we consider it not merely a preparatory draft of Capital (Marx 1867) but a text where we find the best theoretical synthesis of Marx's philosophical and economic writings, and also a text that weaves together the fabric of his historical writings. We should also remember that Marx's ontology is a theory of class struggle founded on the subjectivation of living labour, a constituent ontology rather than a dialectical ontology, even one inverted to "stand on its feet".

Mere inversion, in fact, rarely produces effects that go beyond the critique of the structures of capitalist power - or really, the unmasking of the ideology of the class adversary. And every dialectic that refuses the subjectivising prospects of the conflict and the constituent figure of the project of transformation limits critique to an objectivism (reminiscent of David Ricardo) of the theory of production and to a transcendent or transhistorical perspective of the theory of valorisation.

In contrast, the concept of capital from an ontological perspective is given as an historical figure and one produced by class struggle. In other words, the concept of 
capital is posed in a relationship that recognises, within development, the continuous rupture and recomposition of capitalist command and the resistance of the subjects it puts to work (that is, constant capital and living labour). These appear as asymmetrical and intransitive powers in continuous conflict. This is a real dialectic - one with no Aufhebung, no teleology, and one that is kept always open to class struggle.

When we speak of ontology in this light, we mean simply to plant our feet on the ground. One can debate endlessly with philosophers about what ontology means. Echoing Marx's Theses on Feuerbach, however, we can say that until now philosophers have understood ontology as an idea of being, whereas today must be discovered the ontological conditions of revolutionary praxis. What, then, is the ontology we want to assert, and to which struggles give meaning and direction? It is an ontology of the workers' history, that is, of being that is constructed constantly by the acts of producers, by living labour, by the multitudinous subjectivation that, in cooperation, produces and reproduces the world of life. This frame is where Marxian ontology appears. It describes the world, recognising on one side the productive forces of labour and on the other the forms and relations of production, denouncing the laws of a stupid and unjust order organised on the exploitation in production and the hierarchies in the experience and exercise of power. Marxian ontology is constituted and always renewed by class struggle, by the material antagonism that distributes the elements of real being and by the continuous excess of value that living labour expresses.

This web of relations and these conflicts constitute a landscape on which are developed productions of subjectivity and figures of emancipation adequate to the material forces that express them. Antagonism and class struggle are not, then, powers that are inscribed on a surface over a static foundation. They are powers and movements of all that exists, and they mark a surface that is also a dynamic and subjectivating foundation. They are historical powers that express multitudes of desire.

We should also note here, especially from the perspective of praxis, the importance of Marx's intuition of a tendency for production and reproduction to progressively overlap, an intuition that was renewed and extended by Western Marxism, from Lukács to the Frankfurt School. Gradually the reproductive processes are included in those of production. Against classical economics, for which reproduction is a consequence of production (and primarily included in consumption), on the basis of Marxian ontology there is instead an opening to the inclusion in production of reproduction - and an extension there of antagonism. From this standpoint, the biopolitical perspective can already be gleaned in Marxian ontology. On these bases, then, the socialist feminist argument that women's unwaged domestic labour, which was not included in the standard definitions of "productive labour" of the industrial era, today becomes centrally important - and in some sense paradigmatic - from the standpoint of the definition of exploitation as an extraction of socially produced value. It should not be surprising that a coherent line can be drawn from feminist demands for "wages for housework" to struggles on the terrain of social reproduction and against the patriarchal violence that commands over the family and society.

We should also consider the disruptive and constituent power of the processes of subjectivation that appear on the technological terrain. If one wants to deal with praxis in Marxian terms, then the problem of technology must be central because, with respect to subjectivation, it highlights the political theme of subversion in the era of social production. It is not enough to note here, against many objections, that this theme is posed clearly in the Grundrisse and resolved by Marx in a utopian way. This claim must be theoretically and politically reproposed as a decisive site of critique when considering Marxian praxis in a society where intelligence is put to work at the 
centre of the productive process. Here emerges with great force the theme of the liberation of humans from work, on the basis of the transformations of work. And here the field opens to other objectives of praxis, such as the appropriation of fixed capital by living labour, the overthrow of the alienated conditions in a productive "second nature", and all the themes on which the productivity of worker antagonism demonstrates its power.

Let's consider the call for the appropriation of fixed capital by living labour. This call is not metaphorical. Marx develops it concretely in Capital, and he begins with the demonstration of how the situation of the worker in the face (of the command) of the means of production modifies not only productive capacities but also their figure, nature, and ontology. Central, in this respect, is Marx's account of the passage from the era of manufacture to that of large-scale industry. In manufacture there is still a subjective principle in the division of labour - and that means that the worker appropriates the productive process after the productive process has been adapted to the worker. In large-scale industry, instead, the division of labour is "objective" in the sense that the subjective and artisanal use of the machine is eliminated and machinery is used against humans. The machines not only compete with the workers but also come to command them. But here Marx's reasoning flips and another line appears in Capital, when Marx recognizes that the worker and the means of labour are configured as a hybrid construction and that the conditions of the productive process constitute in large part the conditions of the life of workers, their "form of life". The very concept of the productivity of labour implies a strict and dynamic connection between variable capital and fixed capital. But when the theoretical discoveries, science, the modes of life are taken up again, Marx adds, in the productive process through the experience of workers, this hybrid constitution increases in intensity.

We should remember here that Marx's (1867) analysis in Capital is supported by the argumentation of the Grundrisse (Marx 1857/58), and in particular by the theorisation of the General Intellect as the material and subject of the productive process (Ibid., 706). Marx demonstrates how much cognitive and intellectual activity is central to production, and how much fixed capital is mixed with cognitive labour and its intensified productive power, such that the very concept of fixed capital is transformed by it. When Marx (Ibid., 712) proclaims that fixed capital (which is normally understood as the complex of machines) has become "man himself", he anticipates the development of capitalism in our own time and demonstrates its radical contradictions. Even though fixed capital is produced by labour and is nothing but labour appropriated by capital, even though the accumulation of scientific activity and the productivity of what Marx calls "social intellect" are incorporated in the machines under the control of capital, and even though capital appropriates all this without paying, at a certain point in capitalist development living labour expresses the capacity to exercise the power of inverting this relationship. Living labour demonstrates, that is, its ontological priority with respect to capital and the capitalist management of social production. That means that, whereas constant capital (if it wants to enrich itself) cannot subtract itself from the use of variable capital because it cannot imagine accumulation without the extortion of value from labour of workers. Living labour can transform praxis, that is, the conditions of living, emancipating them from the command of capital. In other words, when it becomes an ever more widespread social power, living labour operates as a more independent activity, outside the disciplinary structures that capital commands - and this is expressed not only as labour-power but also, in a general way, as the productive activity of life. On one hand, past human activity and human intelligence are accumulated, crystallised as fixed capital. But, on 
the other, the flow can be reversed such the living humans are able to reappropriate the productive power of capital, making it their own instrument in the life they live. Fixed capital is "man himself" in both senses.

Here the appropriation of fixed capital is no longer a metaphor but a dispositive that class struggle can adopt and that can be deployed as a political programme. Capital is not longer, in fact, in this case, a relationship that objectively includes the producer, imposing its command by force, but the capitalist relationship includes, now, a final contradiction: that of a producer or a class of producers that can effectively dispossess (in part or wholly) the capitalist owner of the means of production imposing themselves as the hegemonic subject.

In a splendid passage in the Grundrisse Marx poses this double relation: "It requires no great penetration to grasp that, where e.g. free labour or wage labour arising out of the dissolution of bondage is the point of departure, there machines can only arise in antithesis to living labour, as property alien to it, and as power hostile to it; i.e. that they must confront it as capital. But it is just as easy to perceive that machines will not cease to be agencies of social production when they become e.g. property of the associated workers. In the first case, however, their distribution, i.e. that they do not belong to the worker, is just as much a condition of the mode of production founded on wage labour. In the second case the changed distribution would start from a changed foundation of production, a new foundation first created by the process of history" (Marx 1857/58, 832-833).

And this foundation can only be created indeed by revolution.

\section{References}

Harvey, David. 2017. Marx, Capital and the Madness of Economic Reason. London: Profile Books.

Harvey, David. 2003. The New Imperialism. Oxford: Oxford University Press.

Marx, Karl. 1894. Capital: A Critique of Political Economy: Volume Three. London: Penguin.

Marx, Karl. 1885. Capital: A Critique of Political Economy: Volume Two. London: Penguin.

Marx, Karl. 1867. Capital: A Critique of Political Economy: Volume One. London: Penguin.

Marx, Karl. 1857/58. Grundrisse. London: Penguin.

Schumpeter, Joseph. 2017/1934. The Theory of Economic Development. London:

Routledge.

\section{About the Authors}

Michael Hardt

Michael Hardt teaches in the Literature Program at Duke University and is co-director of the Social Movements Lab. He serves as editor of The South Atlantic Quarterly.

\section{Antonio Negri}

Antonio Negri taught at the University of Padua and the University of Paris VIII. He has been one of the central figures of Italian autonomist Marxism. His work is devoted to studies of political philosophy and the analysis of capitalism and globalization.

Hardt and Negri have co-authored the books Labor of Dionysus (1994), Empire (2000), Multitude (2004), Commonwealth (2009), Declaration (2012), and Assembly (2017). Their books are considered to be among the most influential works in political philosophy today. 